\title{
TRANSIT ORIENTED DEVELOPMENT (TOD) IN KAWASAN BAKRIE NIRWANA RESIDENCE MULYA HARJA
}

\author{
Muhammad Agil Al Munawar, Tedy Murtejo, Rulhendri Rulhendri, Nurul Chayati \\ Civil Engineering Study Program, Ibn Khaldun University Bogor, INDONESIA \\ E-mail: muhammadagilalmunawar90@gmail.com
}

\begin{abstract}
The regional development plan and integrated transportation network in the city of Bogor, especially in the Bogor Nirwana Residence Mulya Harja area, requires a plan for determining transit-based movements. The concept of transit oriented development (TOD) is a spatial engineering approach that focuses its development around transit points. The space developed in a transit-oriented area has the characteristics of high density, various mixes (updates) and a design area that is friendly to pedestrians and bicycle users. As for anticipating the emergence of transportation problems in the development of the TOD area, a study is carried out on the analysis of potential generation and attraction to find out how much movement is entering a zone or leaving a zone.to predict the amount of traffic pull generation to and from the TOD area development location. Data collection techniques include existing observations, traffic surveys and document review. The analysis of land use designation refers to the standards and regulations related to the development of transit-oriented areas, while the calculation of the generation of attraction uses the coefficient of ITE (Institute Transportation Engineers) Generation 9th. The results of the research are the level of conformity of the Basic Building Coefficient (KDB), Building Floor Coefficient (KLB) and Green Base Coefficient $(\mathrm{KDH})$ on land use designation on the application of the TOD concept in the BNR area. The results were KDB with a preset rate of $64 \%$, KLB with a percentage rate of 3.28 and KDH of $10 \%$. In the calculation results of the movement generation obtained in the study area with a total of 2,118 (trips/hour), while for the results of the movement of the movement obtained in the study area with a total of 31,780 (trips/hour).
\end{abstract}

Keywords: transit Oriented Development; BNR; land use; generation; attraction.

\begin{tabular}{cccc}
\hline Received: & Revised: & Accepted: & Available online: \\
2020-06-20 & $2020-11-09$ & $2020-12-19$ & $2021-04-15$ \\
\hline
\end{tabular}

\section{INTRODUCTION}

Bogor City is one of the cities located in West Java which has an area of $118.50 \mathrm{~km} 2$, consists of 6 Districts and 68 Kelurahan and has a high population density because the population in 2019 is $1.19 \%$, namely 1.2 million people (Central Agency Bogor City Statistics, 2019). In Bogor Nirwana Residence (BNR) housing located in the South Bogor area in Mulya Harja Village, which has an area of 400 hectares, which is located directly adjacent to the city center, has community activities that can attract visitors from inside and outside the city as an area of limited economic development, directed to the main activities are centers of automotive, shopping tourism, accommodation services and ecotourism so that it has quite large community activities.

The BNR Mulya Harja area is one of several areas in the city of Bogor which will be used as a TOD transit-oriented area. The existence of the BNR, which will be traversed by the Bogor Inner Ring Road (BIRR) ring road and the Bogor LRT Loop Line, is an opportunity to develop a connectivity system in the BNR area, especially at the BNR LRT Loop Line station inside the housing. Because the city of Bogor, especially in the BNR area, has the opportunity to be used as a designation for a transit area that is tailored to the character of the area, which can optimize the potential as an appropriate transit area. In the designation of transit-oriented areas, intermodal facilities and transit areas are inseparable aspects, 


\section{Transit Oriented Development}

Transit Oriented Devlovment (TOD) is the concept of developing areas within and around transit nodes so that added value focuses on the integration between mass public transport networks and non-motorized transportation modes, reducing the use of motorized vehicles accompanied by the development of mixed, dense areas with moderate to moderate space utilization intensity. high. (Permen ATR/BPN No. 16 of 2017).

\section{Generation and Withdrawal}

Awakening is the number of movements originating from a land use (zone) while attraction is the amount of movement towards a zone. Movement generation is a modeling stage that estimates the amount of movement originating from a zone or land use and the amount of movement attracted to a land use or zone. Traffic movement is a land use function that produces traffic movements(Tamin, 2000). This traffic generation includes:

1. Traffic leaving a location

2. Traffic to or from a location

The output from the calculation of traffic generation and attraction is the number of vehicles, people, or goods per unit of time, for example vehicles / hour. We can easily count the number of people or vehicles entering or leaving a certain land area in one day (or one hour) to get the generation and attraction of the movement.

In each determining policies related to road traffic based on the standard regulations set by the government. So that there will be no more violations of traffic on the highway. With this concept, the journey of people to the place of activity will be more comfortable (Syaiful, A.Lutfi, 2015); (Thamsrin, Syaiful, 2016); (S.Syaiful, A.Fadly, 2020). This activity that is delivered indicates that the community needs good and mutually supportive conditions, so that it is hoped that in the future there will be no more disturbances in the field including motorized vehicles including the environment and noise (M.Mubarak, et.al, 2020); (S.Syaiful, S.W.Mudjanarko, 2019); (S.Syaiful, N.Nurwahid, 2020); S.Syaiful, Y.Elvira, 2017).

\section{RESEARCH METHODS}

The location of this research was conducted in the Bogor Nirwana Residence area, Kelurahan Mulya Harja Bogor Selatan. The research time was carried out from March to April 2020. 
Muhammad Agil Al Munawar, Tedy Murtejo, Rulhendri Rulhendri, Nurul Chayati

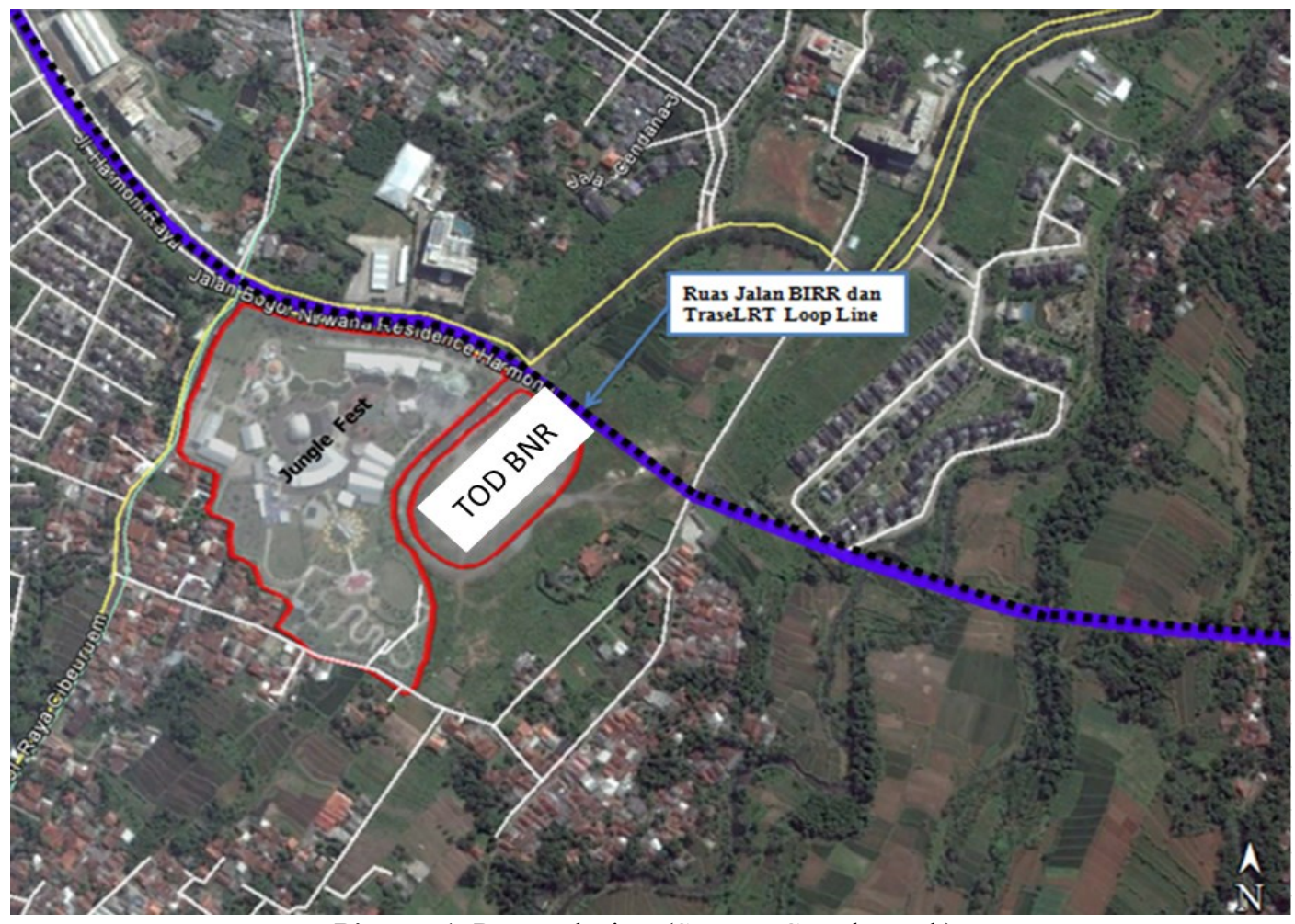

Picture 1. Research sites (Source: Google earth)

The stages of this research are shown in the form of a flow chart as follows:

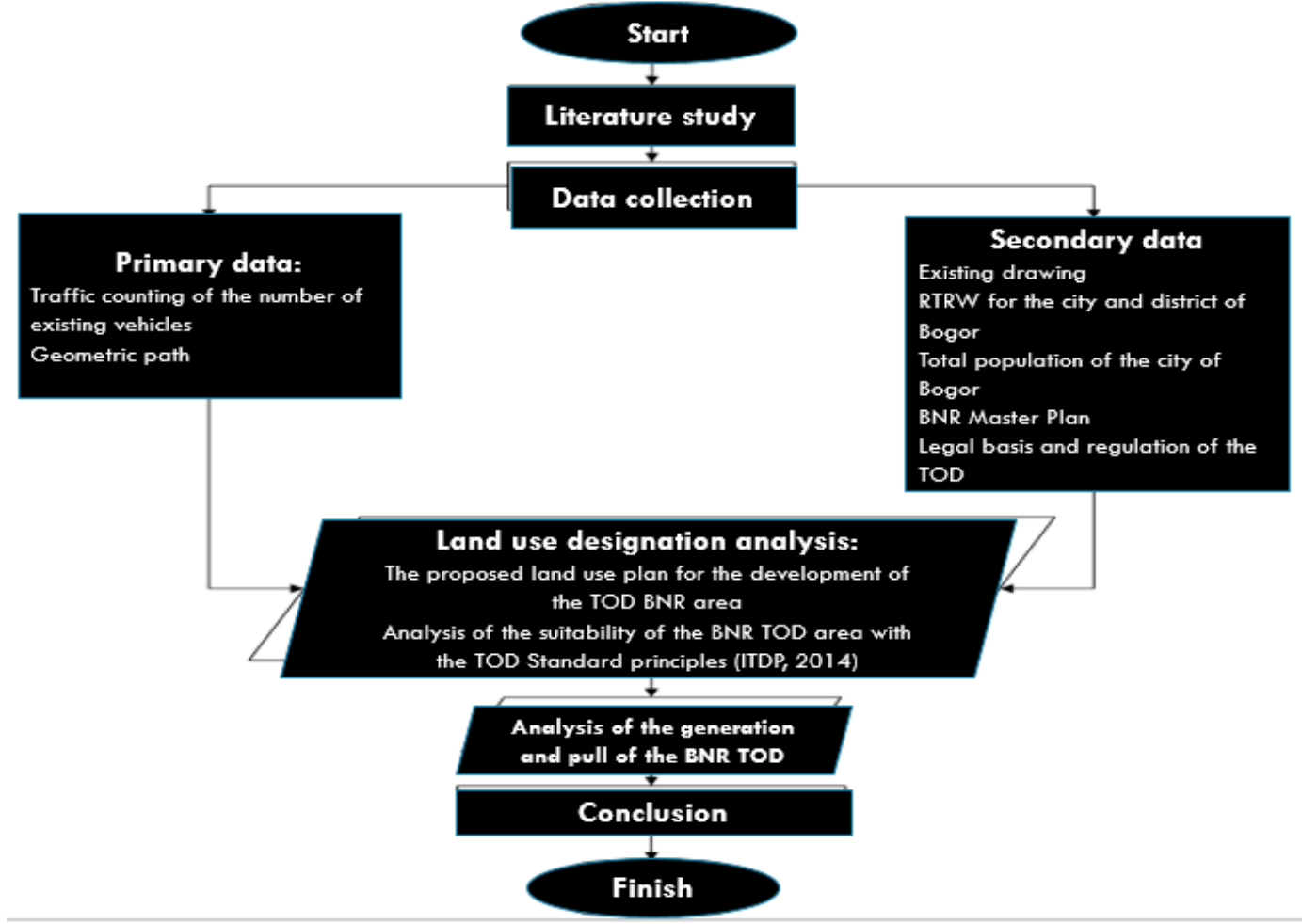

Figure 2. Research flow chart 


\section{RESULTS AND DISCUSSION}

\section{Survey Results}

The traffic survey was carried out on eleven roads in the vicinity of the BNR TOD development plan, which are described in the table below.

Table 1. Characteristics of roads around the study area

\begin{tabular}{clcc}
\hline No. & \multicolumn{1}{c}{ Street Name } & Road Width $(\mathbf{m})$ & Road Type \\
\hline 1 & Cibereum Highway No. & 6 & $2 / 2 \mathrm{UD}$ \\
2 & Kosasiah Way & 7 & $2 / 2 \mathrm{UD}$ \\
3 & Pabuaran Street & 4 & $4 / 2 \mathrm{UD}$ \\
4 & Captain Yusuf's Way & 6 & $2 / 2 \mathrm{UD}$ \\
5 & Street. Harmony Jaya & 4 & $4 / 2 \mathrm{D}$ \\
6 & Jalan Soemanto Direja & 6 & $2 / 2 \mathrm{UD}$ \\
7 & Protected Path & 7 & $2 / 2 \mathrm{UD}$ \\
8 & Arjuna Street & 6 & $2 / 2 \mathrm{UD}$ \\
9 & Cibereum Highway No. 1 & 4 & $2 / 2 \mathrm{UD}$ \\
10 & Jalan BNR Orchard Walk No.1 & 4 & $4 / 2 \mathrm{UD}$ \\
11 & Jalan BNR Orchard Walk No.2 & & $4 / 2 \mathrm{UD}$ \\
\hline
\end{tabular}

(Source: Analysis results)

\section{Road Section Capacity Calculation}

The calculation of road capacity based on MKJI 2017 is stated in the following table:

$\mathrm{C}=\mathrm{C} 0 \times \mathrm{FCW} \times \mathrm{FCPA} \times \mathrm{FCHS}$

Table 2.Road segment capacity

\begin{tabular}{|c|c|c|c|c|c|c|c|c|}
\hline \multirow{3}{*}{ No. } & \multirow{3}{*}{ Street Name } & \multirow{3}{*}{$\begin{array}{l}\text { Road } \\
\text { Type }\end{array}$} & \multicolumn{4}{|c|}{ Adjustment factor for base capacity } & \multirow{3}{*}{$\begin{array}{l}\text { City } \\
\text { size } \\
\text { FCes }\end{array}$} & \multirow{3}{*}{$\begin{array}{c}\text { Capacity } \\
\text { (C) } \\
\text { cur / } \\
\text { hour }\end{array}$} \\
\hline & & & \multirow{2}{*}{$\begin{array}{c}\begin{array}{c}\text { Basic } \\
\text { capacity }\end{array} \\
\text { Co }\end{array}$} & \multirow{2}{*}{\begin{tabular}{|c|}
$\begin{array}{c}\text { Lane } \\
\text { width }\end{array}$ \\
FCw
\end{tabular}} & \multirow{2}{*}{$\begin{array}{c}\begin{array}{c}\text { Direction } \\
\text { Separator }\end{array} \\
\text { FCsp }\end{array}$} & \multirow{2}{*}{$\begin{array}{c}\text { Resistance } \\
\text { FCHs }\end{array}$} & & \\
\hline & & & & & & & & \\
\hline 1 & Jl Ciberem No.2 & $2 / 2 \mathrm{UD}$ & 2900 & 0.87 & 1 & 0.89 & 1 & 2245 \\
\hline 2 & Jl Kosasiah & $2 / 2 \mathrm{UD}$ & 2900 & 1 & 1 & 0.92 & 1 & 2668 \\
\hline 3 & Jl Pabuaran & 4/2 UD & 6000 & 1 & 1 & 0.95 & 1 & 5700 \\
\hline 4 & Jl Kapten Yusuf & $2 / 2 \mathrm{UD}$ & 2900 & 0.87 & 1 & 0.92 & 1 & 2321 \\
\hline 5 & Jl Harmony Jaya & $4 / 2 \mathrm{D}$ & 6600 & 1.08 & 1 & 0.98 & 1 & 6985 \\
\hline 6 & $\begin{array}{l}\text { Jl Soemanto } \\
\text { Direja }\end{array}$ & 2/2 UD & 2900 & 0.87 & 1 & 0.92 & 1 & 2321 \\
\hline 7 & Jl Nyalindung & 2/2 UD & 2900 & 1 & 1 & 0.92 & 1 & 2668 \\
\hline 8 & $\mathrm{Jl}$ Arjuna & 2/2 UD & 2900 & 1 & 1 & 0.92 & 1 & 2668 \\
\hline 9 & $\begin{array}{l}\text { main Street } \\
\text { Cibereum No. } 1\end{array}$ & $2 / 2 \mathrm{UD}$ & 2900 & 0.87 & 1 & 0.89 & 1 & 2245 \\
\hline 10 & $\begin{array}{l}\text { Jl BNR Orchard } \\
\text { Walk No.1 }\end{array}$ & 4/2 UD & 6000 & 1.09 & 1 & 1 & 1 & 6540 \\
\hline 11 & $\begin{array}{l}\text { Jl BNR Orchard } \\
\text { Walk No. } 2\end{array}$ & 4/2 UD & 6000 & 1.09 & 1 & 1 & 1 & 6540 \\
\hline
\end{tabular}

(Source: Analysis results) 
The recapitulation of vehicle volume flows in the TOD BNR area is shown in the following table:

Table 3. Recapitulation of vehicle volume

\begin{tabular}{|c|c|c|c|c|}
\hline No. & Street Name & Directions & $\begin{array}{c}\text { Drajat of } \\
\text { Saturation }\end{array}$ & Los \\
\hline \multirow{2}{*}{1} & \multirow{2}{*}{ Jl Raya Cibereum No. 2} & North South & 0.36 & B \\
\hline & & South North & 0.32 & $\mathrm{~B}$ \\
\hline \multirow{2}{*}{2} & \multirow{2}{*}{ Jl Kosasiah } & West East & 0.1 & A \\
\hline & & East West & 0.1 & A \\
\hline \multirow{2}{*}{3} & \multirow{2}{*}{ Jl Pabuaran } & West East & 0.05 & A \\
\hline & & East West & 0.04 & A \\
\hline \multirow{2}{*}{4} & \multirow{2}{*}{ Jl Kapten Yusuf } & North South & 0.34 & B \\
\hline & & South North & 0.32 & $\mathrm{~B}$ \\
\hline \multirow{2}{*}{5} & \multirow{2}{*}{ Street. Harmony Jaya } & East West & 0.05 & A \\
\hline & & West East & 0.05 & A \\
\hline \multirow{2}{*}{6} & \multirow{2}{*}{ Jl Soemanto Direja } & South North & 0.19 & A \\
\hline & & North South & 0.22 & B \\
\hline \multirow{2}{*}{7} & \multirow{2}{*}{ Jl Nyalindung } & East West & 0.63 & $\mathrm{D}$ \\
\hline & & West East & 0.14 & A \\
\hline \multirow{2}{*}{8} & \multirow{2}{*}{ Jl Arjuna } & South North & 0.14 & A \\
\hline & & North South & 0.15 & A \\
\hline \multirow{2}{*}{9} & \multirow{2}{*}{ Jl Raya Cibereum No. 1} & South North & 0.21 & A \\
\hline & & North South & 0.17 & A \\
\hline \multirow{2}{*}{10} & \multirow{2}{*}{ Jl BNR Orchard Walk No.1 } & North South & 0.13 & A \\
\hline & & South North & 0.1 & A \\
\hline \multirow{2}{*}{11} & \multirow{2}{*}{ Jl BNR Orchard Walk No.2 } & North South & 0.2 & A \\
\hline & & South North & 0.17 & A \\
\hline
\end{tabular}

Based on the results of the calculation of the volume of vehicles in the table above, the peak or highest volume of each road segment is obtained with an hourly time interval and a time period 
starting at 06.00-18.00. Then to describe the volume of vehicles from each road segment, it can be seen in the graph below:

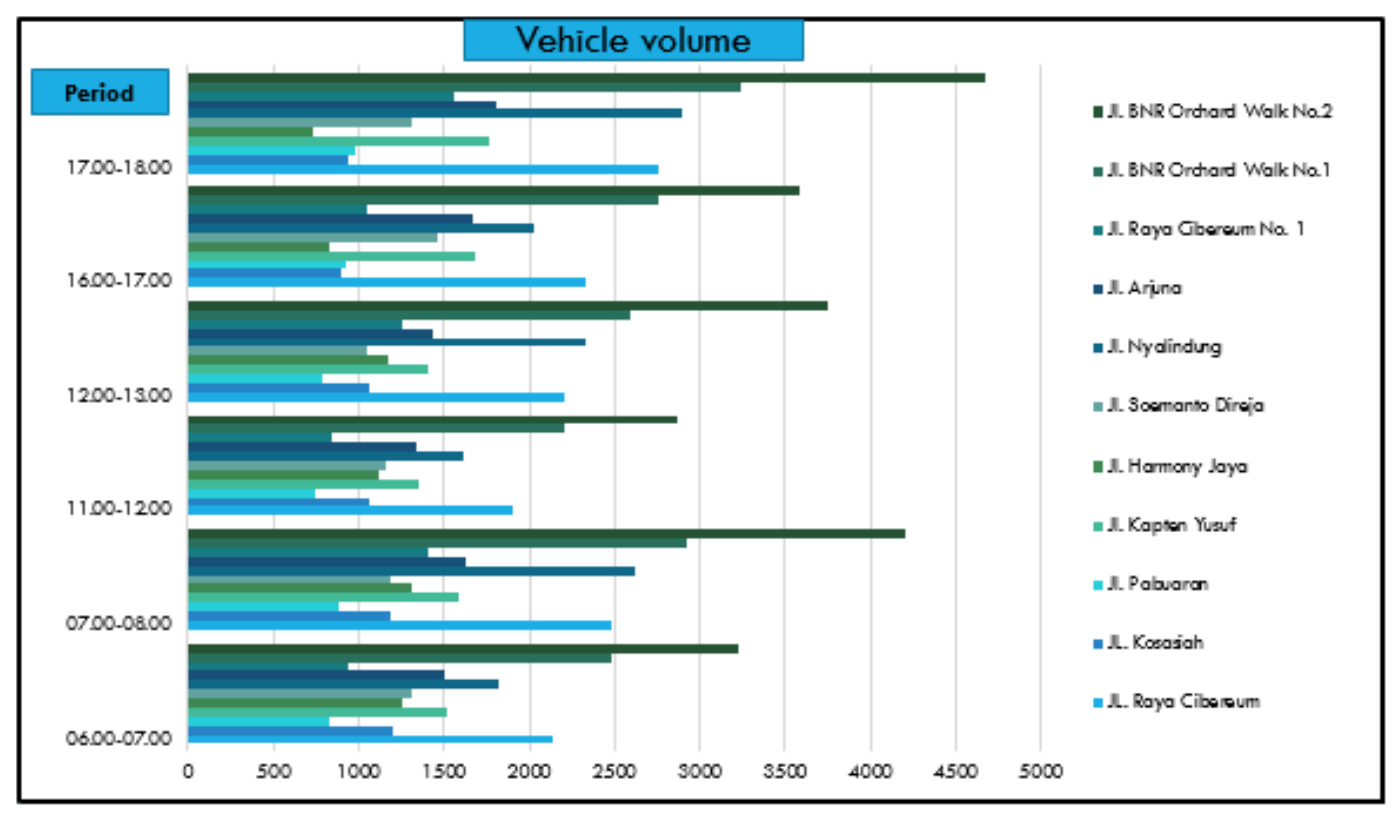

Figure 3. Vehicle Volume in the BNR TOD Area (Source: Analysis results)

\section{Study Zone Conditions}

The study areas are located in several areas including the sub-districts of South Bogor, Central Bogor, East Bogor, Ciomas and Cijeruk which have several villages from each of these sub-districts. The zoning table for the regions is shown in the following table:

Table 4. Zoning in the study area

\begin{tabular}{cll} 
No. & \multicolumn{1}{c}{ Kelurahan } & Districts \\
\hline 1 & Ex. Mulya Harja & \\
2 & Ex. Pamoyanan & \\
3 & Ex. Tile & \\
4 & Ex. Rancamaya & \\
5 & Ex. Muarasari & \\
6 & Ex. Cipaku & South Bogor \\
7 & Ex. Rangga Mekar & \\
8 & Ex. Bojongkerta & \\
9 & Ex. Harjasari & \\
10 & Ex. Tajur & \\
11 & Ex. Cikaret & \\
12 & Ex. Pakuan & \\
\hline
\end{tabular}

(Source: Analysis results)

\section{Origin Destination Matrix}


MAT is a two-dimensional matrix that contains information about the amount of movement between zones within a certain area. The row represents the origin zone and the column represents the destination zone, so that each matrix cell represents the magnitude of the movement flow that moves from the origin zone $\mathrm{i}$ to the destination zone $\mathrm{d}$. The origin destination matrix table is shown in the following table:

Table 5.Origin destination matrix in the TOD BNR study area

\begin{tabular}{|c|c|c|c|c|c|c|c|c|c|c|c|c|c|c|}
\hline Matriks OD & N. & 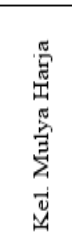 & 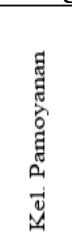 & 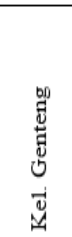 & 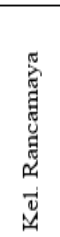 & 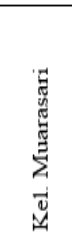 & 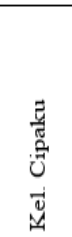 & 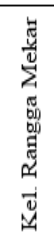 & 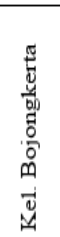 & 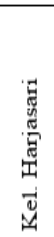 & 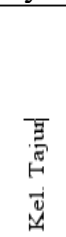 & 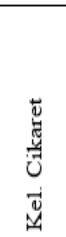 & 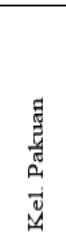 & 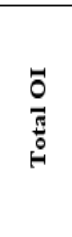 \\
\hline & \begin{tabular}{|l|} 
No \\
\end{tabular} & 1 & 2 & 3 & 4 & 5 & 6 & 7 & 8 & 9 & 10 & 11 & 12 & $\mathrm{OI}$ \\
\hline Kel. Mulya Harja & 1 & 0 & 88 & 218 & 111 & 130 & 98 & 135 & 91 & 324 & 108 & 315 & 106 & 1,724 \\
\hline Kel. Pamoyanan & 2 & 250 & 0 & 98 & 98 & 88 & 206 & 239 & 165 & 145 & 102 & 220 & 87 & 1,697 \\
\hline Kel. Genteng & 3 & 326 & 217 & 0 & 34 & 1,594 & 508 & 47 & 31 & 18 & 209 & 177 & 98 & 3,258 \\
\hline Kel. Rancamaya & 4 & 95 & 98 & 61 & 0 & 1,573 & 683 & 62 & 57 & 33 & 60 & 237 & 243 & 3,201 \\
\hline Kel. Muarasari & 5 & 98 & 88 & 658 & 42 & 0 & 2,166 & 31 & 73 & 30 & 103 & 299 & 306 & 3,893 \\
\hline Kel. Cipaku & 6 & 326 & 306 & 76 & 16 & 788 & 0 & 16 & 53 & 23 & 76 & 161 & 166 & 2,007 \\
\hline Kel. Rangga Mekar & 7 & 215 & 239 & 23 & 10 & 95 & 193 & 0 & 12 & 13 & 23 & 27 & 27 & 877 \\
\hline Kel. Bojongkerta & 8 & 87 & 206 & 274 & 17 & 1,124 & 1,673 & 61 & 0 & 109 & 147 & 92 & 321 & 4,111 \\
\hline Kel. Harjasari & 9 & 326 & 163 & 343 & 41 & 1,407 & 1,131 & 41 & 239 & 0 & 135 & 393 & 117 & 4,338 \\
\hline Kel. Tajur & 10 & 326 & 108 & 61 & 8 & 183 & 147 & 10 & 23 & 5 & 0 & 69 & 39 & 979 \\
\hline Kel. Cikaret & 11 & 360 & 316 & 90 & 20 & 686 & 219 & 20 & 25 & 26 & 66 & 0 & 196 & 2,023 \\
\hline Kel. Pakuan & 12 & 133 & 100 & 107 & 43 & 2,049 & 888 & 24 & 102 & 59 & 78 & 90 & 0 & 3,673 \\
\hline Total DD & $\mathrm{DD}$ & 2,542 & 1,928 & 2,008 & 439 & 9,717 & 7,912 & 686 & 871 & 786 & 1,107 & 2,081 & 1,704 & 31,780 \\
\hline
\end{tabular}

(Source: Analysis results)

In the calculation of the origin destination matrix, the movement in the zone in the study area was found to be 31.780 cur / hour and it was predicted that for one demad day it would reach 317.8 cur/day. The Desire line or the line of desire to travel in the TOD BNR study area uses the original destination matrix that has been charged and is then modeled in the SATURN application shown in the following Figure:

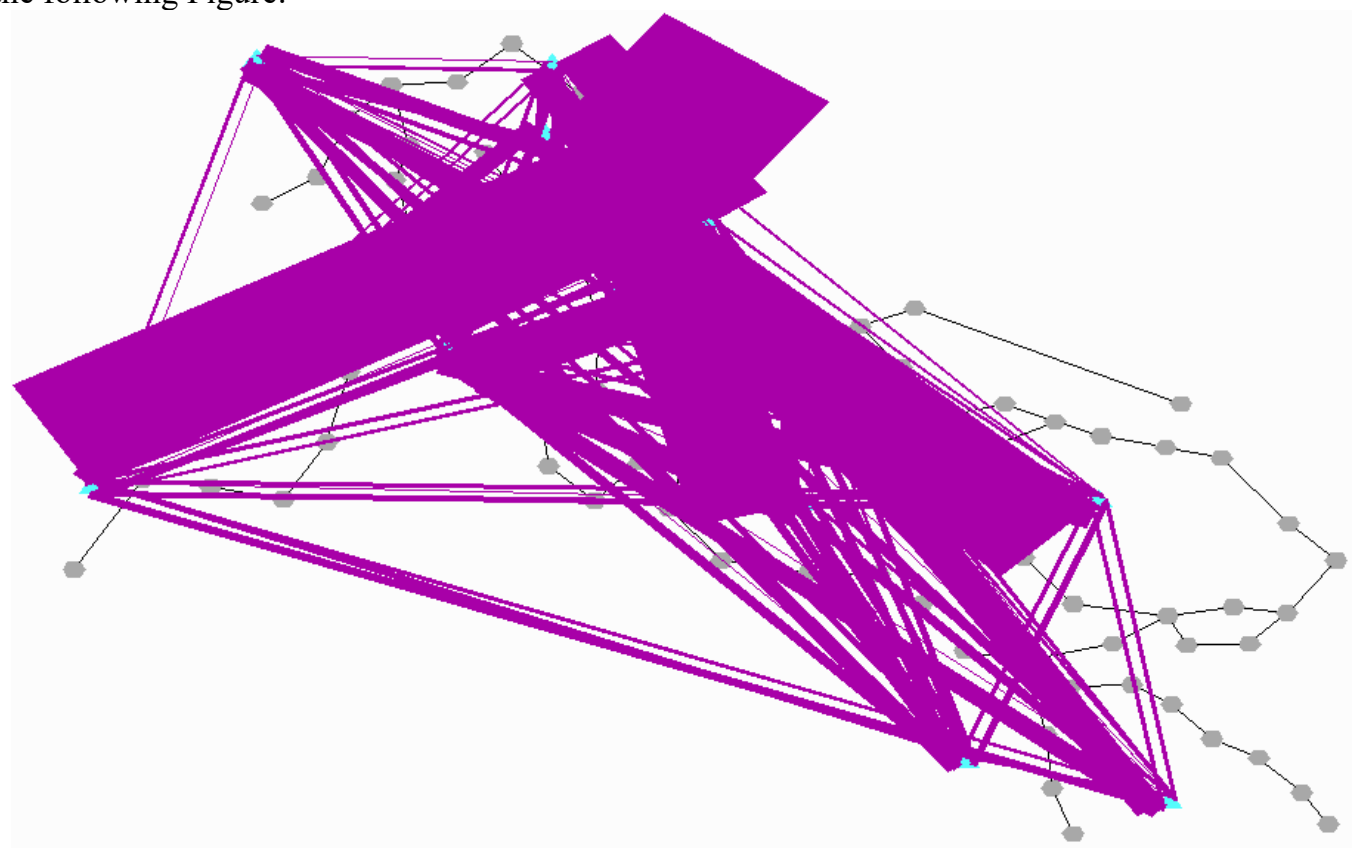

Figure 4. Desair line or the MAT wish line, the year 2020 (Source: Analysis results) 
After doing the MAT modeling in Saturn, the results of the traffic counting survey data are assigned to all road network models on each road section in the study area, so that the traffic volume on all the road networks studied is known. The results of traffic counting on the road network in the study area are shown in the following figure:

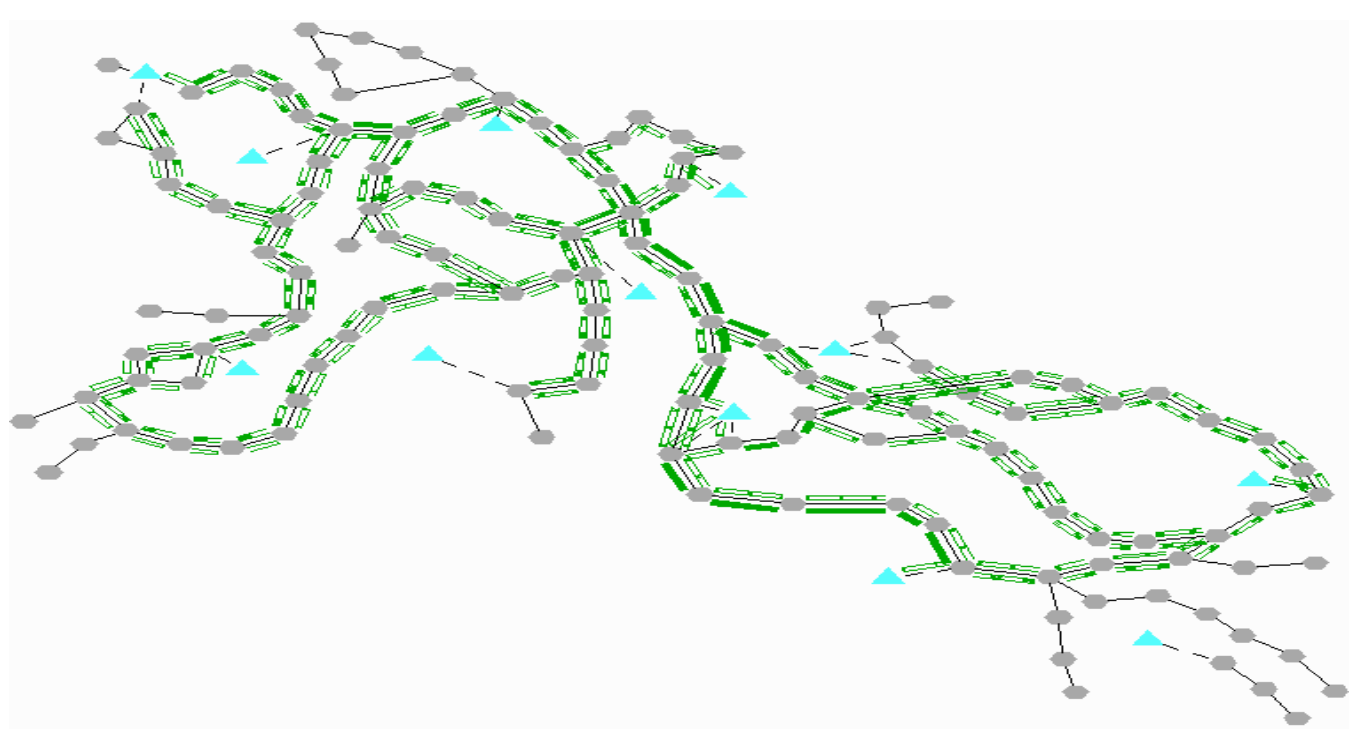

Figure 5. The results of the traffic count loading in the study area (Source: Analysis results)

\section{Land Use Allocation Analysis}

The component of mixed use designation. This is applied to the BNR TOD site where there is a mix of land use between residential land uses such as residential and non-residential such as commercial. Analysis of the site area and floor area with the results of the percentage of KDB and KLB is shown in the following table:

Table 6. Analysis of site area and percentage of KDB

\begin{tabular}{cclccc}
\hline \multirow{2}{*}{ No. } & Block & Land Allocation & Footprint $\left(\mathbf{m}^{\mathbf{2}}\right)$ & KDB & TotalKDB \\
\hline 1 & & F & Appartment & 1050 & $11 \%$ \\
2 & D & Hotel & 980 & $10 \%$ & \\
3 & E & Office & 860 & $9 \%$ & \\
4 & B & Mall & 1360 & $14 \%$ & $64 \%$ \\
5 & C & Retail & 820 & $8 \%$ & \\
6 & A & Park and Ride & 1300 & $13 \%$ & \\
7 & G. & RTH & 480 & & \\
\hline \multicolumn{7}{c}{ Sub-Total } \\
\hline
\end{tabular}

(Source: Analysis results)

Table 7. Analysis of floor area and percentage of outbreaks

\begin{tabular}{cccccccc}
\hline & & \multicolumn{5}{c}{ Building Floor } \\
No. Block & $\begin{array}{c}\text { Land } \\
\text { Allocation }\end{array}$ & $\begin{array}{c}\text { Floor Area } \\
\left(\mathbf{m}^{2}\right)\end{array}$ & $\begin{array}{c}\text { Number } \\
\text { of Floors }\end{array}$ & $\begin{array}{c}\text { Total } \\
\text { Floor } \\
\text { Area }\end{array}$ & Outbreak & TotalKLB \\
\hline 1 & F & Appartment & 900 & 14 & 12600 & 1.26 & 3.28
\end{tabular}




\begin{tabular}{|c|c|c|c|c|c|c|}
\hline 2 & $\mathrm{D}$ & Hotel & 860 & 7 & 6020 & 0.60 \\
\hline 3 & $\mathrm{E}$ & Office & 710 & 5 & 3550 & 0.36 \\
\hline 4 & B & Mall & 930 & 4 & 3720 & 0.37 \\
\hline 5 & $\mathrm{C}$ & Retail & 780 & 3 & 2340 & 0.23 \\
\hline 6 & A & Park and Ride & 1150 & 4 & 4600 & 0.46 \\
\hline
\end{tabular}

(Source: Analysis results)

Table 8. Recapitulation of land use designation

\begin{tabular}{|c|c|c|c|c|c|c|}
\hline \multicolumn{7}{|c|}{ Land Size: $10000 \mathrm{~m}^{2}$} \\
\hline & \multirow{3}{*}{$\begin{array}{l}\text { Space Utilization } \\
\text { Intensity }\end{array}$} & \multicolumn{2}{|c|}{ Footprint } & \multicolumn{3}{|c|}{ Building Floor } \\
\hline & & $\begin{array}{c}\text { Footprint } \\
\text { area }\end{array}$ & $\begin{array}{l}\text { Total } \\
\text { KDB }\end{array}$ & $\begin{array}{l}\text { Number } \\
\text { of Floors }\end{array}$ & $\begin{array}{c}\text { Total Floor } \\
\text { Area }\left(\mathbf{m}^{2}\right)\end{array}$ & $\begin{array}{l}\text { Total } \\
\text { KLB }\end{array}$ \\
\hline \multicolumn{6}{|c|}{ Closed Area } & \\
\hline 1 & Residential & 2030 & & $7-14$ & 18620 & \\
\hline 2 & Non-Residential & 4340 & $64 \%$ & $3-5$ & 14210 & 3.28 \\
\hline & Sub-Total & 6370 & & & 32830 & \\
\hline \multicolumn{7}{|c|}{ Open Area } \\
\hline 1 & RTH & 1000 & \multicolumn{4}{|c|}{ Total Land Area $\mathbf{m}^{2}$} \\
\hline 2 & Street & 2630 & \multicolumn{4}{|c|}{ Closed Space + Open Space } \\
\hline & Sub-Total & 3630 & \multicolumn{4}{|c|}{$10000 \mathrm{~m}^{2}$} \\
\hline
\end{tabular}

(Source: Analysis results)

Prediction of TOD area generation calculation with the calculation method Institute Transport Engineers (ITE)

The calculation of generation is a quantity that shows the movements that can be generated by a land use function in the area. The generation estimate in this study uses the coefficient from the 9th Generation of ITE (Institute Transportation Engineers), which is calculated based on the ITE coefficient unit with the unit or total floor area of the building (ha) in the TOD area. The results of the calculation of the generation in the TOD BNR development area (trip/hour) are shown in the following table:

Table 9. Calculation of the BNR TOD area generation (Trip/Hour)

\begin{tabular}{|c|c|c|c|c|c|c|c|}
\hline No. & Amenities & $\begin{array}{l}\text { Description } \\
\text { (ITE Code) }\end{array}$ & Units & $\begin{array}{l}\text { Sqm } \\
\text { GFA }\end{array}$ & Unit & $\begin{array}{c}\text { ITE } \\
\text { coefficient }\end{array}$ & $\begin{array}{c}\text { ITE } \\
\text { Awakening } \\
\text { (Trip / } \\
\text { Hour) }\end{array}$ \\
\hline 1 & Appartment & Residential & $\begin{array}{c}\text { Dwelling } \\
\text { Units }\end{array}$ & & $\begin{array}{c}315 \\
\text { Units }\end{array}$ & 0.46 & 145 \\
\hline 2 & Hotel & Lodging & Rooms & & $\begin{array}{l}153 \\
\text { Units }\end{array}$ & 0.53 & 81 \\
\hline 3 & Office & Office & $\mathrm{KSF}^{2}$ & 3550 & $\begin{array}{c}38.21 \\
\text { SF }\end{array}$ & 1.56 & 60 \\
\hline 4 & Mall & Retail & $\mathrm{KSF}^{2}$ & 3720 & $\begin{array}{c}40.04 \\
\mathrm{SF}\end{array}$ & 0.96 & 38 \\
\hline 5 & Retail & Retail & $\mathrm{KSF}^{2}$ & 2340 & $\begin{array}{c}25.19 \\
\mathrm{SF}\end{array}$ & 3.81 & 96 \\
\hline 6 & $\begin{array}{l}\text { Park and } \\
\text { Ride }\end{array}$ & $\begin{array}{l}\text { Port and } \\
\text { Terminal }\end{array}$ & $\begin{array}{l}\text { Parking } \\
\text { Space }\end{array}$ & & 2392 & 0.71 & 1698 \\
\hline
\end{tabular}




\begin{tabular}{ccccccc}
\hline No. Amenities & $\begin{array}{c}\text { Description } \\
\text { (ITE Code) }\end{array}$ & Units & $\begin{array}{c}\text { Sqm } \\
\text { GFA }\end{array}$ & Unit & $\begin{array}{c}\text { ITE } \\
\text { coefficient }\end{array}$ & $\begin{array}{c}\text { ITE } \\
\text { Awakening } \\
\text { (Trip / } \\
\text { Hour) }\end{array}$ \\
\hline Sub-Total & & 9610 & & 2118 \\
\hline
\end{tabular}

(Source: Analysis results)

In the generation calculation shown in table 9, the generated land use movement generated in the TOD BNR area is 2,118 trips / hour and it is predicted that for one day the number of generation is 21,180 trips/hour.)

The calculation of the generation in the BNR TOD development area (pcu/hour) is shown in the following table:

Table 10.Calculation of the generation of the BNR TOD area (Smp / Hour)

\begin{tabular}{|c|c|c|c|c|c|c|c|}
\hline $\begin{array}{l}\mathbf{N} \\
\text { o. }\end{array}$ & $\begin{array}{l}\text { Land } \\
\text { Allocation }\end{array}$ & $\begin{array}{c}\text { ITE } \\
\text { Awakeni } \\
\text { ng } \\
\text { (trip/hou } \\
\text { r) } \\
\end{array}$ & BC & KR & $\begin{array}{c}\text { SMe } \\
\text { mp } \\
0.2\end{array}$ & $\begin{array}{l}\text { KRe } \\
\text { mp } 1\end{array}$ & $\begin{array}{c}\text { Awakeni } \\
\text { ng (pcu / } \\
\text { hour) }\end{array}$ \\
\hline 1 & $\begin{array}{l}\text { Appartmen } \\
\mathrm{t}\end{array}$ & 145 & \multirow{7}{*}{$\begin{array}{c}77.32 \\
\%\end{array}$} & \multirow{7}{*}{$\begin{array}{c}22.59 \\
\%\end{array}$} & 22 & 33 & 55 \\
\hline 2 & Hotel & 81 & & & 13 & 18 & 31 \\
\hline 3 & Office & 60 & & & 9 & 13 & 23 \\
\hline 4 & Mall & 38 & & & 6 & 9 & 15 \\
\hline 5 & Retail & 96 & & & 15 & 22 & 37 \\
\hline 6 & $\begin{array}{l}\text { Park and } \\
\text { Ride }\end{array}$ & 1698 & & & 263 & 384 & 646 \\
\hline & Ib-Total & 2118 & & & 328 & 479 & 806 \\
\hline
\end{tabular}

(Source: Analysis results)

Based on the results of the land use movement generation, TOD BNR from trip / hour is converted to $\mathrm{pcu} /$ hour by using the average vehicle data from the traffic count results on each road section, the number of generated generation is $806 \mathrm{pcu} /$ hour.

\section{CONCLUSION}

From the results of the analysis of land use designation in the TOD BNR area, the suitability of the Basic Building Coefficient (KDB) in the residential area includes appartments and hotels by $21 \%$ and commercial areas including offices, malls, retail, and park and ride at $44 \%$, the total value of KDB obtained throughout the building is $64 \%$ of the maximum land cover (land coverage) in the TOD of the city service sub-center by $70 \%$ which is contained in the technical criteria for TOD development based on the type of TOD. The suitability figure for the Building Floor Coefficient (KLB) obtained in the residential area is 1.86 and the commercial area is 1.42 , so the total KDB figure is 3.28 from a maximum number of 3.0 to 4.0. Based on the calculation of generation and attraction, the number of generation obtained in the TOD BNR area is 2,118 trips / hour, and for a pull of 31,780 cur / hour. Because the BNR TOD area is directed to main ecotourism activities, accommodation services, shopping tours and automotive centers as stated in the RTRW of the city of Bogor. 


\section{REFERENCE}

Arsyad MA and Handayeni KD, 2018. Measuring the Conformity of Blok M Transit Areas, Jakarta Against the Criteria for the TOD Concept (Transit Oriented Development) in 2018.

Bishop, Zane. 2015. Transit-Oriented Development: Benefits and Studies. Virginia: Ball State University.

BPS. 2020. Bogor City in 2020 Figures, Bogor City Statistics Agency, Bogor.

BPTJ, 2017. BPTJ Regulation No. Homework. 377/AJ.208/BPTJ-2017 concerning Technical Guidelines for Transportation Aspects in the Implementation of TOD Area Development in the JABODETABEK Area.

Bogor City Regional Regulation, 2016. BCRR No. 11 of 2016 concerning the Bogor City Spatial Planning 2011-2036.

Calthrope Associates. 1993. Transit Oriented Development Design Concepts. San Jose: Transpotation Agency.

Hendarsin, Shirley L. 2000, Highway Engineering Planning, Engineering Department Civil Politeknik Negeri Bandung, Bandung.

Institute for Transportation Development Policy, TOD Standard, New York, 2014.

Ministry of ATR/BPN. 2017. Regulation of the Minister of ATR BPN RI No. 16 of 2017 concerning Guidelines for the Development of Transit Oriented Areas.

Muwahidin, HA, 2019. Development Strategy for the Transit Oriented Development TOD in Bekasi City in 2019.

MKJI (2017) Indonesian Road Capacity Manual. 2017th edn. Jakarta: Ministry of Public Works.

Priadmaja, AP, 2017. Application of the Transit Oriented Development (TOD) Concept in Regional Arrangement in Tangerang City in 2017.

PP, 2011. PP No.32/2011. Government Regulation 32 of 2011 concerning Management and Engineering, Impact Analysis, and Traffic Demand Management.

SNI 03-7112-2005, regarding Aviation Operation Safety Area (KKOP). (Indonesian).

Syaiful, Lutfi Akbar, 2015. Analisis Pengaruh Kecepatan Lalu lintas Terhadap Kebisingan yang Ditimbulkan Kendaraan Bermotor. ASTONJADRO Jurnal Rekayasa Sipil, 4 (1), pp.13-19. (Indonesian). http://ejournal.uika-bogor.ac.id/index.php/ASTONJADRO/article/view/818

Syaiful, 2015. Tingkat Resistensi Polusi Suara di Depan RSIA Sentosa Bogor. ASTONJADRO Jurnal Rekayasa Sipil, 4 (2), pp.57-61.(Indonesian). http://ejournal.uikabogor.ac.id/index.php/ASTONJADRO/article/view/828

Thamrin, Syaiful, 2016. Analisis Kebisingan yang Ditimbulkan Kepadatan Kendaraan Bermotor (Studi Kasus Depan Masjid Assalafiyah, Jl. Raya Sukabumi KM 22 Cigombong, Kabupaten Bogor), ASTONJADRO Jurnal Rekayasa Sipil, 5(2).pp.46-57. (Indonesian). http://ejournal.uikabogor.ac.id/index.php/ASTONJADRO/article/view/839

S Syaiful, A Fadly, 2020. Analysis Of The Effectiveness Of Bus Services Outside Of Campus IPB Dramaga Bogor, ASTONJADRO: JURNAL REKAYASA SIPIL 9 (2), 173-186. http://ejournal.uika-bogor.ac.id/index.php/ASTONJADRO/article/view/3597

M Mubarak, R Rulhendri, S Syaiful, 2020. Perencanaan Peningkatan Perkerasan Jalan Beton Pada Ruas Jalan Babakan Tengah Kabupaten Bogor, ASTONJADRO: JURNAL REKAYASA SIPIL 9
(1),
$1-13$.
(Indonesian).
http://ejournal.uika-

bogor.ac.id/index.php/ASTONJADRO/article/view/2694 
Syaiful Syaiful, Sri Wiwoho Mudjanarko, 2019. Noise of Motor Vehicles at from of Baiturrahman Great Mosque Semarang City, THE SPIRIT OF SOCIETY JOURNAL 2 (2), 131-149. DOI: https://doi.org/10.29138/scj.v2i2 https://jurnal.narotama.ac.id/index.php/scj/article/view/902

S Syaiful, N Wahid, 2020. A STUDY OF THE DENSITY OF MOTOR VEHICLES IN FRONT OF HOSPITAL BUNDA MARGONDA DEPOK AGAINST NOISE POLLUTION, THE SPIRIT

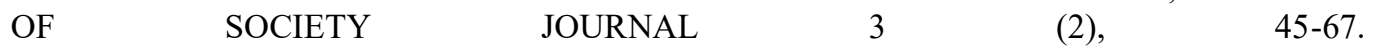

https://jurnal.narotama.ac.id/index.php/scj/article/view/1094

S Syaiful, Y Elvira, 2017. CASE STUDY ON USE AREA PARKING AT NEW MARKET CITY SHOPPING CENTER BOGOR, International Journal of Tranportation And Infrastructure (IJTI) 1 (1), 15-23. https://jurnal.narotama.ac.id/index.php/ijti/article/view/330

Tricks, Roger., 1986. Finding Lost Space. Van Nostrand Reinold Company, New York.

Tamin, O. 2000. Planning 7 Transportation Modeling. Second. Bandung. (Indonesian).

UU, 2007. Law of the Republic of Indonesia Number 26 of 2007 concerning Spatial Planning 